\title{
Urethral Reconstruction in a Reference Center in Eastern Colombia
}

\section{Reconstrucción uretral en un centro de referencia del oriente colombiano}

\author{
Verónica Tobar-Roa ${ }^{1}$ Ana María Ortiz-Zableh ${ }^{2}$ Daniel José Mantilla-Rey ${ }^{2}$ \\ Guillermo Sarmiento-Sarmiento ${ }^{1}$ \\ ${ }^{1}$ Foscal Urological Center, Universidad Autónoma de Bucaramanga, \\ Floridablanca, Colombia \\ 2 Universidad Autónoma de Bucaramanga, Floridablanca, Colombia \\ Address for correspondence Ana María Ortiz, MD, Universidad \\ Autónoma de Bucaramanga (UNAB), Floridablanca, Colombia \\ (e-mail: aortizz.92@gmail.com).
}

Urol Colomb 2020;29:26-31.

\begin{abstract}
Introduction and Objectives Urethral stricture is a complex pathology of multiple etiologies, and of unknown incidence in our country. There are multiple options for the management of urethral stricture, from minimally invasive procedures, like urethral dilation or direct vision internal urethrotomy, to open surgical reconstruction using excision and primary anastomosis (EPA), or augmented urethroplasty with tissue graft. The aim of the present study is to describe the characteristics of the patients managed with urethral reconstructive surgery in a reference center in eastern Colombia.

Methods Observational retrospective cohort study. Data was obtained from patients undergoing urethral reconstructive surgery at the institution from August 2013 to December 2017. All of the surgeries were performed by the same surgical team. The clinical and demographic variables were collected, and the validated urethral stricture surgery patient-reported outcome measure (USS-PROM) questionnaire was applied.

Results A total of 56 patients were included in the study, 26 patients (46.4\%) underwent excision and primary anastomosis (EPA), and 30 (53.6\%) underwent graft urethroplasty. The average age at the time of the intervention was 53.3 years old. The most frequent etiology was trauma, and the mean length of the stenosis was $1.7 \mathrm{~cm}$ for the EPA group, and $3 \mathrm{~cm}$ for the graft urethroplasty group $(p=0.009)$. A history of previous surgery was found in $66 \%$ of the patients, and radiotherapy in 2 patients. The mean follow-up was of 14 months (range: $0-52$ months), observing similar success rates for both techniques. Despite of the small sample size, when analyzing the KaplanMeier curves, we observed a tendency of a better response in the group without

Keywords

- urethra

- urethral stricture

- reconstructive surgical procedures

- surgical anastomosis. previous treatments and with stenosis with a length $<2 \mathrm{~cm}$.

The rate of postoperative complications was of $23 \%$, with no statistical difference between the 2 groups. The USS-PROM questionnaire was applied to 29 patients, finding that 27 out of 29 respondents were satisfied with the results of the procedure, and all of them would recommend it to another person.
\end{abstract}

received

April 29, 2019

accepted

August 21, 2019
DOI https://doi.org/

$10.1055 / \mathrm{s}-0039-1698797$.

ISSN 0120-789X.

e ISSN 2027-0119.
Copyright (c) 2020, Sociedad Colombiana License terms de Urología. Publicado por Thieme Revinter Publicações Ltda., Rio de Janeiro, Brazil. Todos los derechos reservados. 


\section{Resumen}

Conclusions The results of our study show that urethral reconstruction surgery performed in an experienced center is associated with a good success rate, and that patients are satisfied with the result of the procedure.

Introducción y objetivos La estrechez uretral es una patología compleja, de etiología múltiple e incidencia aún desconocida en nuestro país. Existen múltiples opciones de manejo dependiendo de las características de la estrechez, desde procedimientos mínimamente invasivos, como la dilatación uretral o uretrotomía interna, hasta la reconstrucción uretral abierta mediante escisión y anastomosis primaria (EPA) o cirugía de ampliación con injerto.

El objetivo de este estudio es describir las características de los pacientes llevados a cirugía reconstructiva uretral en un centro de referencia del oriente colombiano.

Métodos Estudio observacional de cohorte retrospectiva. Se obtuvieron datos de pacientes sometidos a cirugía reconstructiva uretral en la institución desde agosto de 2013 hasta diciembre de 2017. Todas las cirugías fueron realizadas por un mismo equipo quirúrgico. Se recolectaron las variables clínicas y demográficas, y se aplicó el cuestionario USS PROM validado a español.

Resultados Se incluyeron 56 pacientes en el estudio: 26 pacientes $(46,4 \%)$ fueron sometidos a EPA y 30 (53,6\%), a uretroplastía con injerto. La edad media al momento de la intervención fue de 53,3 años. La etiología más frecuente fue traumática, y la longitud media de la estenosis fue de $1,7 \mathrm{~cm}$ para el grupo de EPA, y de $3 \mathrm{~cm}$ para el grupo de uretroplastía con injerto $(p=0.009)$. Se encontró antecedente de cirugía en $66 \%$ de los pacientes, y radioterapia en 2 pacientes.

La media de seguimiento fue de 14 meses ( $0-52$ meses), observando una tasa de éxito similar para ambas técnicas. A pesar de la muestra pequeña, al analizar las curvas de Kaplan-Meier observamos una tendencia a una mejor respuesta en aquellos pacientes sin tratamientos previos, y con estenosis menor de $2 \mathrm{~cm}$.

La tasa de complicaciones postoperatorias fue de $23 \%$, sin diferencias estadísticamente significativas entre ambos grupos. Se aplicó telefónicamente el cuestionario USS PROM a 29 pacientes, y se encontró que 27/29 estaban satisfechos con el resultado de la cirugía, y todos la recomendarían a otra persona.

Conclusiones Los resultados de nuestro estudio muestran que la cirugía de reconstrucción uretral realizada en un centro con experiencia se asocia a una buena tasa de éxito, y que los pacientes se encuentran satisfechos con el resultado de esta.

\section{Introduction}

The term urethral stricture refers to a scar formation process that involves the urethral epithelium and/or the erectile tissue of the spongiosa (spongiofibrosis). ${ }^{1}$ It may be secondary to urethral catheterization, to urological instrumentation, to trauma, to inflammatory processes, ${ }^{2}$ and in some cases it may be

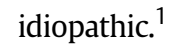

Until a few years ago, most cases of urethral stricture were secondary to inflammatory processes; however, nowadays the main cause of this pathology is iatrogenic., ${ }^{2,3}$

The real incidence of urethral stricture worldwide is unknown. It is estimated that in industrialized countries it is close to $0.9 \%{ }^{2}$ In our country, we do not have statistics on the incidence of this disease. ${ }^{4}$

There are multiple management options depending on the characteristics of the stricture, from minimally invasive pro- cedures, such as urethral dilation or internal urethrotomy, to open urethral reconstruction by excision and primary anastomosis (EPA), or augmented urethroplasty with tissue graft.

Endoscopic management by direct vision internal urethrotomy is generally reserved for patients with short bulbar urethral strictures $<1 \mathrm{~cm}$, achieving success rates between 50 and $75 \%$, but with high recurrence rates. ${ }^{5}$ Despite this, urethrotomy remains the main method of treatment used by urologists in the United States in up to $90 \%$ of the cases. ${ }^{6}$ In contrast, the success rates of EPA in the bulbar urethra is $>90 \%{ }^{7}$ and in patients managed with oral mucosa graft, taking into account all the different techniques available, it is $>85 \% .{ }^{8-10}$

Although endoscopic management is still the most widely used approach for the management of urethral strictures, surgical management with urethroplasty has been increasing in recent years, mainly in academic practice scenarios and in reference centers. $^{11}$ 
The objective of the present study is to describe the characteristics of patients undergoing urethral reconstructive surgery in a reference center in eastern Colombia.

\section{Methods}

An observational retrospective cohort study was performed. Data was obtained from an anonymized database of patients undergoing perineal urethroplasty in our institution from August 2013 to December 2017. We excluded patients managed only with urethral dilatations, internal urethrotomy, perineal urethrostomy, and those who were lost during follow-up. All of the surgeries were performed by the same surgical team.

The clinical and demographic variables were collected, and the urethral stricture surgery patient-reported outcome measure (USS-PROM) questionnaire validated in Spanish was applied by telephone to 29 patients. The patients were divided into two groups according to the type of procedure performed: EPA and graft urethroplasty group. The characteristics of each group were analyzed, as well as the success rate, complication rate, degree of satisfaction and, finally, the patients were asked if they would recommend the procedure to another person. The data was analyzed in IBM SPSS Statistics for Macintosh, Version 25.0. The $p$-value was set at 0.05 for all of the analyses.

\section{Results}

A total of 56 procedures performed on 48 patients were included in the present study. The average age at the time of the intervention was 53.3 years old. A total of 25 patients (44.6\%) had undergone a previous urethral dilation, and 37 (66\%) had undergone a previous urethral surgical procedure (internal urethrotomy or urethroplasty). Two patients had a history of pelvic radiation therapy (-Table $\mathbf{1}$ ).

A total of 26 patients underwent EPA, and 30 underwent graft urethroplasty. The most frequent etiology was traumatic (41\%), and the mean length of the stenosis was $1.7 \mathrm{~cm}$ for the EPA group, and $3 \mathrm{~cm}$ for the graft urethroplasty group $(p=0.009)$. The most frequent location was the bulbar urethra, followed by the penile urethra. The mean followup time was of 14 months (range: $0-52$ months). We found a similar success rate between the EPA technique and the graft

Table 1 Patient Characteristics

\begin{tabular}{|l|l|}
\hline Age (years old) & 53.3 (range: 13-78; SD: 17.2) \\
\hline Length (cm) & 2.4 (range: 0.3-9; SD: 1.78) \\
\hline $\begin{array}{l}\text { Previous } \\
\text { cystostomy** (n, \%) }\end{array}$ & $33(58.9 \%)$ \\
\hline $\begin{array}{l}\text { Presurgical urethral } \\
\text { dilation (n, \%) }\end{array}$ & $25(44.6 \%)$ \\
\hline EPA (n, \%) & $26(46.4 \%)$ \\
\hline Graft urethroplasty (n, \%) & $30(53.6 \%)$ \\
\hline
\end{tabular}

Abbreviation: EPA, excision and primary anastomosis; SD, standard deviation.

**Patients managed with cystostomy prior to surgical correction. urethroplasty group at the end of the follow-up (75.45 versus 76.6\%) (- Table 2 and Graphic 1).

Despite the small sample size, when analyzing the Kaplan-Meier curves, we observed a tendency of better success rate in those patients without previous treatments, and in those with a stenosis $<2 \mathrm{~cm}$, although these differences were not statistically significant. (Graphics $\mathbf{2}$ and $\mathbf{3}$ )

- Table 3 describes the postoperative complications, the most frequent being urinary tract infection (UTI) (8.9\%). There were no statistically significant differences in complications between EPA and graft urethroplasty (53.8 versus $46.1 \%, p=0.541)$.

The USS-PROM questionnaire was applied to 29 patients by telephone, in which they were instructed to rate their health status after surgery on a scale from 0 to 100 , finding an average of 84.1 points (range: $50-100$, standard deviation [SD]: 12.63), and regarding lower urinary tract symptoms, they had an average score of 3.83 (range: 0-16, SD: 4.96); additionally, we conducted the International Index of Erectile Function-5 (IIEF-5) questionnaire with a mean of 16.45 points (5-25, SD: 7.32), indicating mild to moderate erectile dysfunction (ED). We asked the degree of satisfaction with the surgery. A total of 27 patients (93.1\%) were satisfied with the result of the surgery, and all of them would recommend the procedure to another patient.

\section{Discussion}

Initially, the treatment of urethral stricture consisted on urethral dilations until the appearance of internal urethrotomy, described by Sachse in $1972 .^{12}$ These procedures were considered the choice of treatment since they are minimally invasive, simple to perform, ambulatory and low-cost. ${ }^{4,13}$

Despite this, it is known since 1997 that there are no statistically significant differences regarding the rate of success between urethral dilation and internal urethrotomy, ${ }^{14}$ and that the long-term recurrence rate is of up to $82 \%$ with these procedures. ${ }^{2}$ It has also been shown that repeated internal urethrotomy is not cost-effective nor clinically usefull $^{15}$ with stricture recurrence rates of up to $61 \%$ in 48 months, ${ }^{16}$ and of $68 \%$ in 98 months; ${ }^{2}$ therefore, in the last decade, urethroplasty has been positioned as an elective surgery in most of the patients, since it is the therapeutic approach with the greatest success rate, and with the least possibility of stricture recurrence. ${ }^{11,15,17,18}$

In our study, the most frequent etiology of stricture was traumatic ( $41 \%)$, followed by iatrogenic (21\%); these results are similar to those documented by Contreras-García et al, in their study with patients from Valle del Cauca. ${ }^{4}$ Zheri et al, in their cohort study in Pakistan, reported that most of the strictures were idiopathic (32\%), followed by inflammatory (17\%), and, in last place, traumatic (16\%). ${ }^{19}$ On the other hand, in developed countries, the main causes of stricture are idiopathic and iatrogenic. ${ }^{20,21}$

It has been shown that previous surgical intervention in the stricture (either with urethral dilation or internal urethrotomy), increases the risk of recurrence, ${ }^{19}$ and that it is a predictor of therapeutic failure after urethroplasty. ${ }^{22}$ One 
Table 2 Results by Groups: Excision and Primary Anastomosis and Graft Urethroplasty

\begin{tabular}{|c|c|c|c|}
\hline & EPA & Graft urethroplasty & $p$-value \\
\hline No. Patients & 26 & 30 & 0.7570 \\
\hline Age (years old) (median) & $\begin{array}{l}54.35 \\
\text { (range: 13-78; SD: 17.6) }\end{array}$ & $\begin{array}{l}52.47 \\
\text { (range: 15-75; SD: 17.1) }\end{array}$ & \\
\hline Length of stricture in cm (median) & $\begin{array}{l}1.76 \\
\text { (range 0.5-5; SD: 1.2) }\end{array}$ & $\begin{array}{l}3.02 \\
\text { (range 0.3-9; SD: 1.9) }\end{array}$ & 0.0092 \\
\hline \multicolumn{4}{|l|}{ Location of stricture: } \\
\hline Meatal /sub meatal & 0 & 2 & \\
\hline Penile & 1 & 11 & \\
\hline Bulbar & 18 & 13 & \\
\hline Bulbomembranous & 6 & 3 & \\
\hline Pan urethral & 0 & 1 & \\
\hline \multicolumn{4}{|l|}{ Etiology of stricture } \\
\hline Post traumatic & 16 & 7 & \\
\hline Inflammatory & 1 & 8 & \\
\hline latrogenic & 5 & 7 & \\
\hline Idiopathic & 4 & 8 & \\
\hline Surgical time (minutes) & $236.3(120-360)$ & $266.2(72-420)$ & 0.0936 \\
\hline Follow up (months) & $14.58(1-54)$ & $13.13(0-52)$ & 0.8114 \\
\hline Success rate & $19(75.45 \%)$ & $23(76.6 \%)$ & 0.7570 \\
\hline Complications & $7(53.8 \%)$ & $6(46.1 \%)$ & 0.541 \\
\hline
\end{tabular}

Abbreviation: EPA, excision and primary anastomosis; SD, standard deviation.

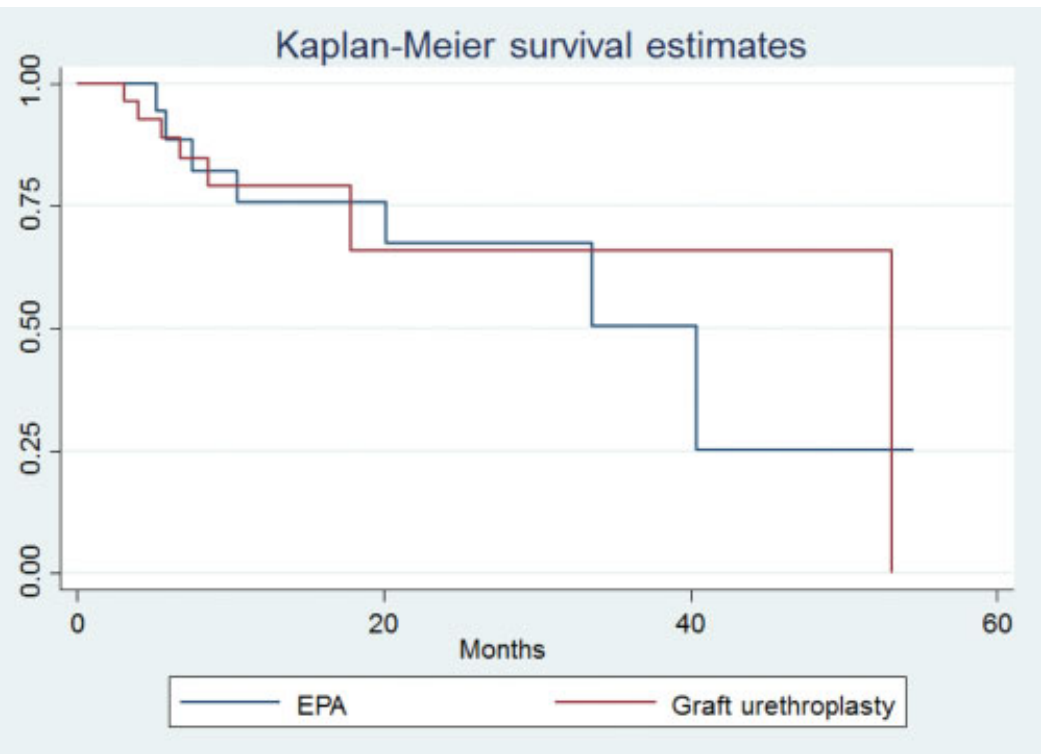

Graphic 1 Survival estimates. Excision and primary anastomosis (EPA) and graft urethroplasty.

third of our patients had previously been operated with internal urethrotomy (66.1\%), and almost half of them (44\%) had gone through a protocol of urethral dilation, which could have been related with our final results.

Prior studies have shown success rates of $>90 \%$ for urethral strictures managed with EPA, and of $>85 \%$ for those treated with graft urethroplasty. In our study, the success rate was similar in both techniques (75.45 versus $76.6 \%$ ), being lower than those reported by other series. This can be associated with the high rate of previously operated patients, and the traumatic etiology of the stricture, both of them being risk factors for therapeutic failure. ${ }^{22,23}$ Additionally, our definition of therapeutic failure was defined as any urethral dilation after surgery, which increases the number 


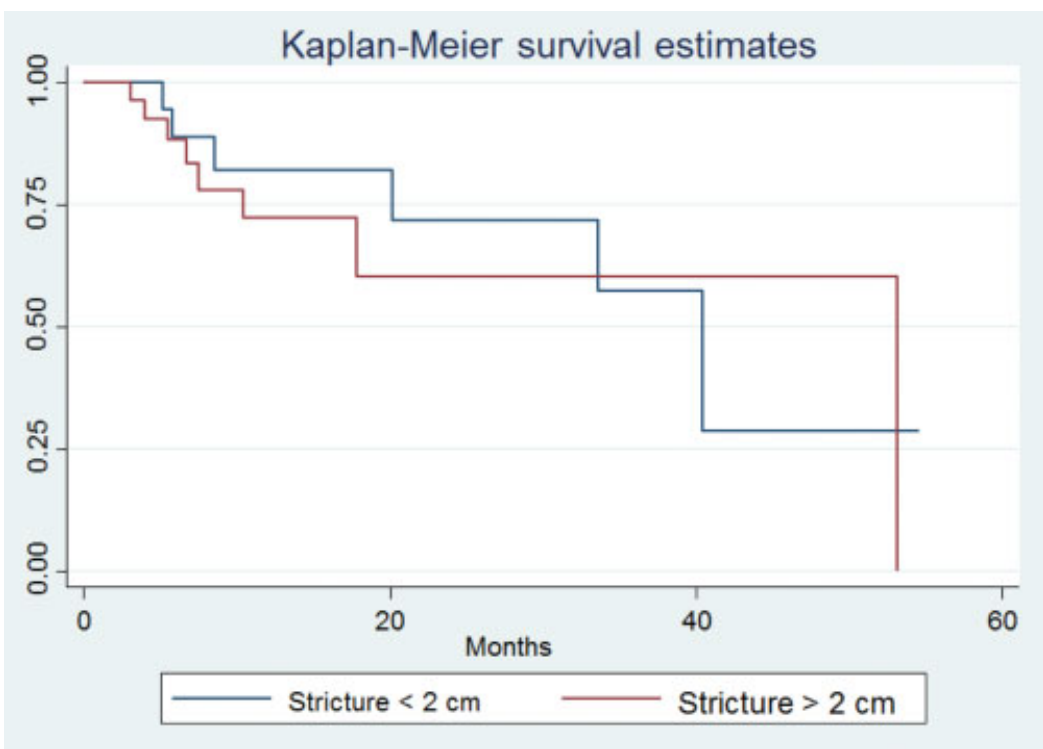

Graphic 2 Survival estimate. Urethral stricture less or greater than $2 \mathrm{~cm}$.

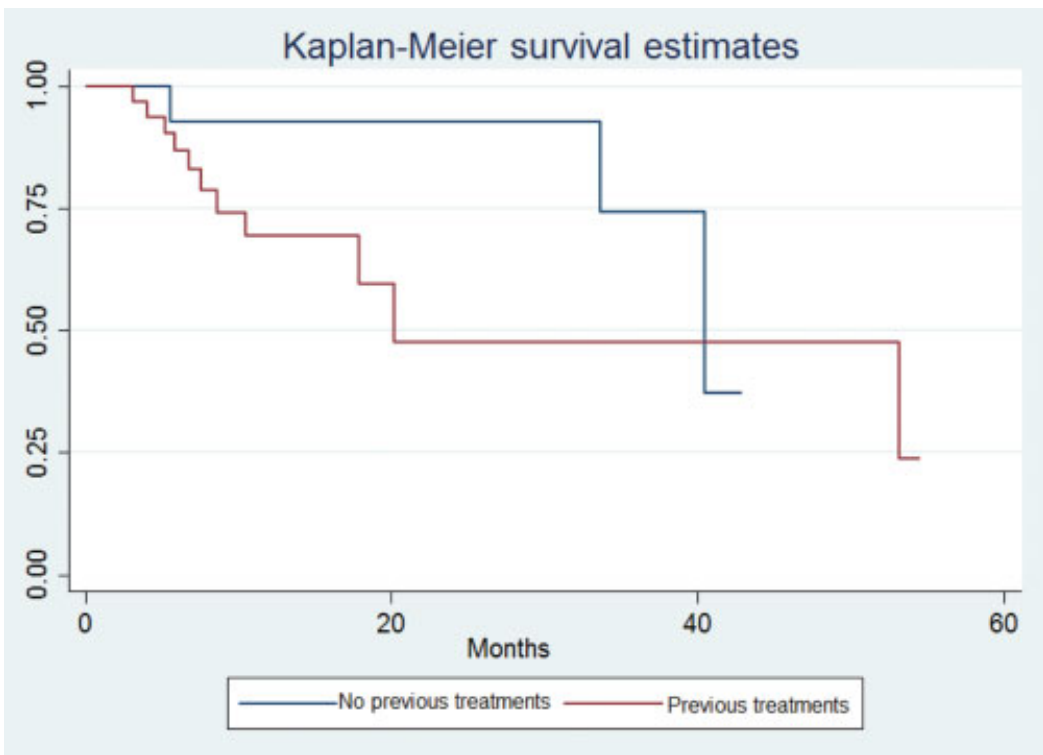

Graphic 3 Survival estimates. Patients with or without previous treatment.

Table 3 Postoperative Complications

\begin{tabular}{|l|l|}
\hline $\begin{array}{l}\text { COMPLICATIONS } \\
(\mathbf{n}, \%)\end{array}$ & $\begin{array}{l}13 \\
(23.2 \%)\end{array}$ \\
\hline UTI & $5(38.5 \%)$ \\
\hline Surgical wound infection & $1(1.7 \%)$ \\
\hline Deep venous thrombosis & $2(15.4 \%)$ \\
\hline Post operative neuropraxia & $2(15.4 \%)$ \\
\hline Perineal pain & $1(1.7 \%)$ \\
\hline Erectile dysfunction & $1(1.7 \%)$ \\
\hline Vesicocutaneous fistula & $1(1.7 \%)$ \\
\hline
\end{tabular}

of patients considered as therapeutic failures. Nonetheless, from a subjective point of view, when applying the USSPROMS tool on our patients, we found that the mean score for obstructive urinary symptoms was low, that the satisfaction grade of the patients was of $93 \%$, and that all of the patients would recommend the procedure to other patients. These results show the high impact of the surgery in the quality of life of the patients. Erickson et al described 2 forms to define success in the management of a reconstructive urethral surgery: an anatomical one, defined as the adequate and not difficult introduction of a flexible cystoscope (16 Fr) through a reconstructed urethra, and a functional one, defined as the feeling of improvement in the obstructive urinary symptoms by the patient. ${ }^{24}$ 
The real incidence of ED after urethroplasty is not known yet; nonetheless, the current literature reveals low rates of de novo ED. ${ }^{25}$ When we applied the IIEF-5 scale postoperatively, we found a mild to moderate prevalence of ED, but since we do not count with preoperative data, we cannot get to conclusions regarding ED.

Our study has limitations, since it is retrospective, with a small sample size, and no objective presurgical data (International Prostate Symptom Score [I-PSS], International Index for Erectil Function (IIEF-5), uroflowmetry), that could allow us to better compare the data. Lastly, our definition of therapeutic failure only takes into account the symptoms referred by the patient, and does not take into account anatomic or functional studies, such as cystoscopy, cystography, or urodynamics, which does not allow us to expand our definition to the ones used in more recent studies. ${ }^{24}$

Our results show high success rates in patients with urethral stricture managed with urethroplasty, as well as a notable improvement in the quality of life in these patients, with a follow-up time of $>1$ year.

\section{Conclusions}

The results of our study show that urethral reconstruction surgery performed in an experienced center is associated with good success rates, that patients are satisfied with the results of the procedure, and that all of them would recommend it to other patients.

\section{Conflict of Interests}

The authors have no conflict of interests to declare.

\section{Acknowledgment}

We would like to thank Dr. Paul Camacho (epidemiologist) for helping us reviewing the statistical data.

\section{References}

1 McCammon KA, Zuckerman JM, Jordan GH. Surgery of the Penis and Urethra. In: Campbell-Walsh urology. 2016:907-945

2 Pansadoro V, Emiliozzi P. Internal urethrotomy in the management of anterior urethral strictures: Long-term followup. J Urol 1996;156(01):73-75

3 Lumen N, Hoebeke P, Willemsen P, De Troyer B, Pieters R, Oosterlinck W. Etiology of Urethral Stricture Disease in the 21st Century. J Urol 2009;182(03):983-987

4 Contreras-García R, García-Perdomo HA, Robayo-Ramirez J. Experiencia en el manejo de la estrechez uretral en un centro de tercer nivel en Colombia. Urol Colomb [Internet] 2017;26(02):98-103. Available from: http://dx.doi.org/10.1016/j.uroco.2016.10.006

5 Anger JT, Buckley JC, Santucci RA, Elliott SP, Saigal CS. Trends in stricture management among male medicare beneficiaries: Underuse of urethroplasty? Urology 2011;77(02):481-486

6 Buckley JC, Patel N, Wang S, Liss M. National Trends in the Management of Urethral Stricture Disease: A 14-Year Survey of the Nationwide Inpatient Sample. Urol Pract [Internet] 2016;3(04):315-320. Available from: http://dx.doi.org/10.1016/j.urpr.2015.07.002

7 Morey AF, Watkin N, Shenfeld O, Eltahawy E, Giudice C. SIU/ICUD consultation on urethral strictures: Anterior urethra - Primary anastomosis. Urology 2014;83(3 SUPPL.):S23-S26
8 Chapple C, Andrich D, Atala A, Barbagli G, Cavalcanti A, Kulkarni S, et al. SIU/ICUD consultation on urethral strictures: The management of anterior urethral stricture disease using substitution urethroplasty. Urology 2014;83(3 SUPPL.)

9 Aldaqadossi H, El Gamal S, El-Nadey M, El Gamal O, Radwan M, Gaber M. Dorsal onlay (Barbagli technique) versus dorsal inlay (Asopa technique) buccal mucosal graft urethroplasty for anterior urethral stricture: A prospective randomized study. Int J Urol 2014;21(02):185-188

10 Palminteri E, Manzoni G, Berdondini E, Di Fiore F, Testa G, Poluzzi $\mathrm{M}$, et al. Combined Dorsal plus Ventral Double Buccal Mucosa Graft in Bulbar Urethral Reconstruction. Eur Urol 2008;53(01): $81-90$

11 Liu JS, Hofer MD, Oberlin DT, Milose J, Flury SC, Morey AF, et al. Practice Patterns in the Treatment of Urethral Stricture among American Urologists: A Paradigm Change? Urology [Internet] 2015;86(04):830-834. Available from: http://dx.doi.org/ 10.1016/j.urology.2015.07.020

12 Sachse H. Zur Behandlung der Harnröhrenstriktur: Die transurethrale Schlitzung unter Sicht mit scharfem Schnitt. Fortschr Med 1974;92:12-24

13 Gómez R, Marchetti P, Castillo OA. Rational and selective management of patients with anterior urethral stricture disease. Actas Urol Esp 2011;35(03):159-166

14 SteenkampJW, Heyns CF, De Kock MLS. Internal urethrotomy versus dilation as treatment for male urethral strictures: A prospective, randomized comparison. J Urol 1997;157(01):98-101

15 Greenwell TJ, Castle C, Andrich DE, MacDonald JT, Nicol DL, Mundy AR. Repeat urethrotomy and dilation for the treatment of urethral stricture are neither clinically effective nor costeffective. J Urol 2004;172(01):275-277

16 Heyns CF, Steenkamp JW, De Kock ML, Whitaker P. Treatment of male urethral strictures: is repeated dilation or internal urethrotomy useful? J Urol [Internet] 1998;160(02):356-358. Available from: http://www.ncbi.nlm.nih.gov/pubmed/9679876

17 Cotta BH, Buckley JC. Endoscopic Treatment of Urethral Stenosis. Urologic Clinics of North America 2017

18 Osterberg EC, Murphy G, Harris CR, Breyer BN. Cost-effective Strategies for the Management and Treatment of Urethral Stricture Disease. Urologic Clinics of North America 2017

19 Zehri AA, Ather MH, Afshan Q. Predictors of recurrence of urethral stricture disease following optical urethrotomy. Int J Surg [Internet] 2009;7(04):361-364. Available from: http://dx.doi.org/10.1016/j. ijsu.2009.05.010

20 Lazzeri M, Sansalone S, Guazzoni G, Barbagli G. Incidence, Causes, and Complications of Urethral Stricture Disease. Eur Urol Suppl [Internet] 2016;15(01):2-6. Available from: http://dx.doi.org/ 10.1016/j.eursup.2015.10.002

21 Stein DM, Thum DJ, Barbagli G, Kulkarni S, Sansalone S, Pardeshi A, et al. A geographic analysis of male urethral stricture aetiology and location. BJU Int 2013;112(06):830-834

22 Breyer BN, McAninch JW, Whitson JM, Eisenberg ML, Mehdizadeh JF, Myers JB, et al. Multivariate Analysis of Risk Factors for Long-Term Urethroplasty Outcome. J Urol [Internet] 2010; 183(02):613-617. Available from: http://dx.doi.org/10.1016/j. juro.2009.10.018

23 Viers BR, Pagliara TJ, Shakir NA, Rew CA, Folgosa-Cooley L, Scott JM, et al. Delayed Reconstruction of Bulbar Urethral Strictures is Associated with Multiple Interventions, Longer Strictures and More Complex Repairs. J Urol 2018;199(02):515-521

24 Erickson BA, Ghareeb GM. Definition of Successful Treatment and Optimal Follow-up after Urethral Reconstruction for Urethral Stricture Disease. Vol. 44, Urologic Clinics of North America. 2017:1-9

25 Dogra PN, Singh P, Nayyar R, Yadav S. Sexual Dysfunction After Urethroplasty. Urologic Clinics of North America 2017 